\title{
Author Correction to: Telomerase subunit Est2 marks internal sites that are prone to accumulate DNA damage
}

Satyaprakash Pandey ${ }^{1 \dagger}$, Mona Hajikazemi ${ }^{2 \dagger}$, Theresa Zacheja ${ }^{2}$, Stephanie Schalbetter ${ }^{3}$, Matthew J. Neale ${ }^{3}$, Jonathan Baxter ${ }^{3}$, Victor Guryev ${ }^{1}$, Andreas Hofmann ${ }^{4}$, Dieter W. Heermann ${ }^{4}$, Stefan A. Juranek ${ }^{{ }^{*}}$ and Katrin Paeschke $e^{5,6^{*}}$

\section{Correction to: BMC Biol 19, 247 (2021)}

https://doi.org/10.1186/s12915-021-01167-1

The original article [1] mistakenly omitted co-author Matthew J Neale and his funding source.

This has since been corrected.

\begin{abstract}
Author details
'University of Groningen, University Medical Center Groningen, European Research Institute for the Biology of Ageing, 9713 AV Groningen, Netherlands. ${ }^{2}$ Clinic of Internal Medicine III, Oncology, Hematology, Rheumatology and Clinical Immunology, University Hospital Bonn, Bonn, Germany. ${ }^{3}$ Department of Life Science, University of Sussex, Brighton, UK. ${ }^{4}$ nstitute for Theoretical Physics, University of Heidelberg, Philosophenweg 12, 69120 Heidelberg, Germany. ${ }^{5}$ Clinic of Internal Medicine III, Oncology, Hematology, Rheumatology and Clinical Immunology, University Hospital Bonn, Bonn, Germany. ${ }^{6}$ University of Groningen, University Medical Center Groningen, European Research Institute for the Biology of Ageing, 9713 AV Groningen, Netherlands.
\end{abstract}

Published online: 01 February 2022

\author{
Reference \\ 1. Pandey $S$, et al. Telomerase subunit Est2 marks internal sites that are \\ prone to accumulate DNA damage. BMC Biol. 2021;19:247. https://doi. \\ org/10.1186/s12915-021-01167-1.
}

The original article can be found online at https://doi.org/10.1186/s12915021-01167-1.

*Correspondence: stefan.juranek@ukbonn.de; katrin.paeschke@ukbonn.de

${ }^{\dagger}$ Satyaprakash Pandey and Mona Hajikazemi contributed equally to this work.

${ }^{5}$ Clinic of Internal Medicine III, Oncology, Hematology, Rheumatology and Clinical Immunology, University Hospital Bonn, Bonn, Germany

Full list of author information is available at the end of the article

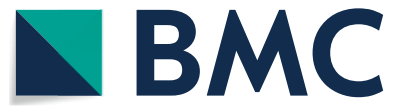

(c) The Author(s) 2022. Open Access This article is licensed under a Creative Commons Attribution 4.0 International License, which permits use, sharing, adaptation, distribution and reproduction in any medium or format, as long as you give appropriate credit to the original author(s) and the source, provide a link to the Creative Commons licence, and indicate if changes were made. The images or other third party material in this article are included in the article's Creative Commons licence, unless indicated otherwise in a credit line to the material. If material is not included in the article's Creative Commons licence and your intended use is not permitted by statutory regulation or exceeds the permitted use, you will need to obtain permission directly from the copyright holder. To view a copy of this licence, visit http://creativecommons.org/licenses/by/4.0/. The Creative Commons Public Domain Dedication waiver (http://creativeco mmons.org/publicdomain/zero/1.0/) applies to the data made available in this article, unless otherwise stated in a credit line to the data. 